\title{
Jorwert Breaking: A Late Old West Frisian Sound Change
}

\author{
Siebren Dyk
}

\section{INTRODUCTION ${ }^{1}$}

More than twenty-five years ago, Henk Meijering called for further investigation in the area of Old Frisian phonology: 'It might be a good idea to take up the study of other linguistic changes which begin to show in the late Old Frisian period [...] like e.g. the $h$-deletion in initial position before a consonant, the so-called younger palatalization of $/ \mathrm{k} /$, the development of (-)ewe(-) to (-)iowe(-)'. ${ }^{2}$ I suspect that Frisian linguistics is not known for its rapid developments but, nevertheless, the first of the three phenomena mentioned by Meijering did subsequently become the subject of one study, ${ }^{3}$ and here I want to take up the third.

It is certainly not the case that the phenomenon in question has never been granted any attention; however, the longest treatment, by Willem van Helten, is now over a century old. ${ }^{4}$ The field of phonology has made some progress since that time, and although van Helten had a good knowledge of Old Frisian, he was handicapped in that he was not well aware of developments in later stages of Frisian. Moreover, neither in van Helten's nor in

\footnotetext{
This article is an abridged and slightly updated version of a paper written in Frisian, 'Jorwertbrekking', IB 64 (2002), 272-314. The most important difference is that I have dropped a complete section on the historiography of the phenomenon which would be of limited importance outside the inner circle of Frisian studies. Furthermore, I have removed a few questionable cases from my analysis that are not essential for the point I am trying to make. - Preparing a new version of an older paper has offered me the pleasant opportunity to express a few words of gratitude again. So, for the second time I may thank Jarich Hoekstra, Arjen Versloot and Willem Visser for commenting on a draft version. I also would like to thank Karel Gildemacher, Henk Meijering and Jenny Visser for each providing me with fresh examples.

2 H. D. Meijering, ' $d(e)$-Deletion in the Past Tense of the Class II Weak Verbs in Old Frisian', Linguistic Studies Offered to Berthe Siertsema, ed. D.J. van Alkemade et al. (Amsterdam, 1980), 277-86, at 285.

3 H. Nijdam, 'The Loss of Old Frisian $h$ in Initial Consonant Clusters', ABäG 51 (1999), 81-104.

4 W. L. van Helten, 'Zur Lexicologie und Grammatik des Altwestfriesischen', BGdSL 19 (1894), 345-440; 560.
} 
later studies has the phenomenon been studied in its own right. At most, it has been mentioned in passing in accounts detailing the possible developments of individual vowels, like /i:/ or /e:/. In etymological studies it was used as an argument to point to the source of the word in question; a good example is Hoekstra's recent study, which connects Modern West Frisian jamk with OFris *evenlik. ${ }^{6}$ Other examples of this genre will come to pass in section 4. In summary, it is fair to say that although the phenomenon is not unknown among Frisian linguists and philologists, it has never been subject to an in depth treatment.

As Meijering has noted, the Old Frisian sequence ew can change into jow; but it is my contention that this is not the only relevant change in this respect. I hope to show that combinations of $w$ and vowels at other heights underwent a similar change, and in my opinion this change can be analysed as a direct one, in that the phonological height remains constant. Putting length distinctions aside, this holds for $/ \mathrm{i}(:) /+/ \mathrm{w} /$, which changes to $/ \mathrm{ju}$.w/, and possibly also for $/ \varepsilon(:) /+/ \mathrm{w} /$, resulting in $/ \mathrm{j}$ o.w/; this idea will be elaborated in section 2 . Section 3 provides some phonological evidence in favour of the position taken here. The bulk of the evidence, however, is to be found in section 4, where an attempt is made to catalogue all the Frisian words which have undergone the process. In section 5 , something will be said about the historical implementation of the change. The story ends in section 6 with a short conclusion.

It should be emphasized that the process under discussion is a feature of (Old) West Frisian only. ${ }^{7}$ In North Frisian and East Frisian it is unknown, possibly, with the exception of a few place-names such as Jukwerd, Joeswerd and Sjuxum in the province of Groningen, i.e. in a formerly East Frisian area. ${ }^{8}$

As can be deduced from the title, I dub the process with the term Jorwert Breaking. 'Breaking' is a well-known phenomenon within the field of Frisian historical phonology. Most commonly, it refers to the change of a

5 See, for instance, the overviews by T. Siebs, Zur Geschichte der englisch-friesischen Sprache (Halle/S., 1889); J. Jacobs, Vormleer van het Oudfriesch werkwoord (Gent, 1899); P. Kloosterman, Het vocalisme der beklemtoonde lettergrepen van den Metslawierschen tongval, historisch uiteengezet. Een bijdrage tot de kennis der historische grammatica van het Nieuwwestfriesch (Groningen, 1907); J. S. H. Boersma, De Friesche oorkonden uit het archief van het St. Anthony-gasthuis te Leeuwarden, II (Amsterdam, 1939).

${ }^{6}$ J. Hoekstra, 'Iampck ist en iamcker wirtet mecke: Jitris oer it komôf fan Nijfrysk jamk', IB 60 (1998), 1-14.

7 The change is seen as a characteristic of Old West Frisian by W. J. Buma, Aldfryske houlikstaspraken (Assen, 1957), 35-36.

8 H. T. J. Miedema, Van York naar Jorwerd. Enkele problemen uit de Friese taalgeschiedenis (Groningen, 1966), 11. 
falling (central) diphthong into a rising one, for example in /stjInən/, the plural of /sti.ən/ 'stone'. This change can be traced back to the Middle Frisian period, around the year 1700 . Although the process is traditionally referred to as 'Modern Frisian Breaking', one cannot say that a monophthong is literally broken into a diphthong here; maybe this change is better described as a shift of accent within the diphthong itself. To be sure, the term 'breaking' is already used for two types of changes in the Old Frisian period. First, there is the breaking of short $e$ into iu or io before the consonant clusters $/ \mathrm{xt} /$ or $/ \mathrm{xs} /$ which produces Old Frisian forms such as fiuchta 'to fight' and riucht 'right'. And, secondly, there is a breaking process before $l+$ consonant clusters, also traceable to the late Old Frisian period, which yields Modern West Frisian forms like fjild 'field', jelmisse 'alms' and jelne 'ell' (measure of length). ${ }^{9}$

In light of the above examples, the term 'breaking' for the process under review does not seem inappropriate. As we will see in the next section, it can be analysed as a shift of accent within the diphthong, a process quite similar to Modern Frisian Breaking. However, judging by the transition e.g. ew $>$ jow, the approximant $w$ seems to be a constant factor, so one could also claim that $e$ polarizes into a rising diphthong $j o$. Let us therefore assume that it is justified to characterize the process as a form of breaking, especially when the Frisian linguistic tradition is taken into account.

Although this type of breaking does not solely occur in Frisian, I have not been able to come across a special term for it, other than 'stress shift'. But stresses can be shifted in many ways and places, so this term does not seem very fitting, and a new term to refer to the process might be in order. I have therefore decided to refer to the process as 'Jorwert Breaking', after the village of Jorwert, some 15 kilometres south-west of Ljouwert (Dutch: Leeuwarden), the capital of the province of Fryslân. This is done for three reasons. First, the first part of its name, Jor-, is a clear example of the process, the name of the village was formerly Everwerd. Second, using the name of this village in reference to the process has a certain tradition: witness Miedema's inaugural lecture Van York naar Jorwerd ('From York to Jorwerd'). And last but not least, it so happens that I became an inhabitant of the village. Had I not moved to Jorwert, I am sure this article would never have been written.

\footnotetext{
9 For these two types of 'breaking' process, see, respectively, D. Boutkan, 'On Labial Mutation and Breaking in Old Frisian', Approaches, 77-88, and H. T. J. Miedema, 'Friese plaatsnamen, tweetaligheid, brekingen en andere problemen', Naamkunde 19 (1987), 104-41.
} 


\section{ANALYSIS}

The existence of Jorwert Breaking in Frisian, especially on such a large scale, is unthinkable without the weakening, i.e. vocalization of $/ \mathrm{v} /$ in Old Frisian. ${ }^{10}$ The weakening could result in a deletion of $/ \mathrm{v} /$ after $r$ and $l$, cf. MoFris stjerre 'to die' from /sterva/ and keal 'calf' from /kalv/. In intervocalic position, $v$ could vocalize to the approximant $w$, e.g. OFris skriva /skri:va/ 'to write' changed to /skri:wa/.

As a second point of departure for my analysis, I assume that Old Frisian had four vowel heights. Although some scholars are undecided on this point, ${ }^{11}$ this position is already alluded to by Theodor Siebs, and defended by Pieter Sipma, Henricus Miedema and Dietrich Hofmann; furthermore, on the basis of later developments in West Frisian dialects, Arjen Versloot has also concluded that there were two $\bar{e}$ 's in Old West Frisian. ${ }^{12}$ In this paper I also take the position that there were two $\bar{e}$ 's, but as we will see later, it may be useful to keep an eye on this as yet unresolved question. As to both $\bar{e}$ 's, the open one, here symbolized by [ $\varepsilon$ :], developed from a former long $* a i$ and * $x y$ (from Germanic ai and au plus $i$-umlaut, respectively), while closed [e:] derived from PGmc $\bar{e}, \bar{o}$ and $\bar{u}$ by $i$-umlaut. One difficulty lies in the fact that both $\bar{e}$ 's were not differentiated in Old Frisian orthography. However, thanks to the notation in Holthausen's Altfriesisches Wörterbuch the two are easily identified, as this dictionary registers the reflexes from the long monophthongs as $\bar{e}$ and the reflexes from the old diphthongs as $\hat{e}$. Arne Spenter assumes even five vowel heights for the long vowels in Old West Frisian, ${ }^{13}$ but it is unlikely that such a constellation would have formed a stable system. Therefore, I prefer a four-height system as in (1): ${ }^{14}$

10 In this sense G. Gosses ('Snjeon', De Pompebledden 13 [1940], 39-43, at 40) was completely right in characterizing 'de $\mathrm{V}$ as moater' ['V (functions) as a motor'].

11 E.g. T. L. Markey, Frisian (The Hague, 1981), 109, and J. Hoekstra, 'An Outline History of West Frisian', Handbuch / Handbook, 722-34, at 725; D. Boutkan, 'Phonology and Orthographic System of Old Frisian', ibid. 613-20, at 618.

12 T. Siebs, Der Vocalismus der Stammsilben in der altfriesischen Sprache (Halle/S., 1885), 22; P. Sipma, Fon Alra Fresena Fridome. In ynlieding yn it Aldfrysk (Sneek, 1947), 55-56; H. T. J. Miedema, 'Oer de fokaelsystemen fan Reyner Bogerman en Gysbert Japiks as oergongssstadia tusken Ald- en Nijfrysk', Fryske stúdzjes oanbean oan Prof. dr. J. H. Brouwer op syn sechstichste jierdei 23 augustus 1960, ed. K. Dykstra et al. (Assen, 1960), 153-60; D. Hofmann, “"Germanisch” $\overline{\mathrm{e}}^{2}$ im Friesischen', in D. Hofmann, Gesammelte Schriften, 2 vols. (Hamburg, 1988-1989) II, 165-90; A. Versloot, 'Aldwesterlauwersk Fryske /e:/ yn it Nijwesterlauwersk Frysk', IB 53 (1991), 71-96.

13 A. Spenter, Der Vokalismus der akzentuierten Silben in der Schiermonnikooger Mundart. Eine geschichtliche Studie des autochthonen westfriesischen Inseldialekts (Copenhagen, 1968), 150.

14 I present the vowels here as long, but Old Frisian also had short vowels before /v/. 
(1)

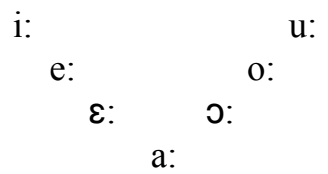

As long as $v$ was a fricative, it belonged to the onset of a following syllable, e.g. OFris skri-va. However, as a glide $w$, it became an ambisyllabic transition sound between two syllables. Hence, $w$ became the last element of the preceding syllable and merged with the preceding vowel. ${ }^{15}$ This kind of contraction caused Modern West Frisian to differ somewhat more from neighbouring languages. It resulted in such forms as nâle 'navel', hauk 'hawk' (Du havik), Aldehou 'church tower in Leeuwarden' (Du Oldehove), do 'pigeon' (Du duif), and îne 'oven' (Du oven).

Applied to the schema in (1), the contraction of $w$ yields the following combinations:

(2)

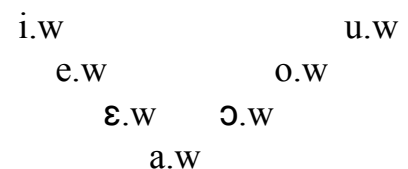

In the contraction process, the original long vowel was undoubtedly shortened somewhat, and the original short vowels will have been lengthened. The net result is indicated here by a single dot. For ease of reference I will use the term 'diphthong' for this result, although I leave open the question whether this is correct, i.e. whether $w$ is part of the nucleus of the syllable or should be situated outside of it.

After contraction, a further process of diphthongization took place. And this is what I call 'Jorwert Breaking'. The front vowel becomes a back vowel which itself is preceded by the palatal glide /j/. Since /a.w/ cannot be retracted, this combination is not involved in the process. As to $a(:)$ and vocalized $v$, there was only contraction to /a.w/, which later merged with /o.w/. ${ }^{16}$

\footnotetext{
See D. Hofmann, 'Die "spätgermanische" Silbenquantitätsverschiebung und die Doppelschreibung alter kurzer Konsonanten in den altwestfriesischen Quellen', Gesammelte Schriften, II, 206-14, at 210.

16 Hoekstra, 'An Outline History of West Frisian', 727.
} 
Nature, according to a sound basic assumption, is organized in a simple way. Therefore, it would be most natural to assume that vowel height in this operation remains constant, hence the following schema:

(3)

$$
\begin{aligned}
& \text { i.w }>\text { ju.w } \\
& \text { e.w }>\text { jo.w } \\
& \text { E.w }>\text { jo.w }
\end{aligned}
$$

Now, I would like to claim that this is what did actually take place, and I shall provide evidence for this stance in the next sections. At this point, it can already be detected from the schema that in Jorwert Breaking three falling diphthongs are involved. Two of these diphthongs result from two distinct varieties of $e$-such a differentiation has never been suggested in the literature on Jorwert Breaking until now. This notion of vowel height retention is new, as will emerge in the discussion of some earlier proposals later on in this section.

Superficially, 'Jorwert Breaking' is reminiscent of back-mutation, in the literature also referred to as $u$ - or $w$-Umlaut, labial mutation, etc. ${ }^{17} \mathrm{~A}$ few Modern Frisian examples which once underwent that change follow below: ${ }^{18}$

\section{(4)}

njoggen 'nine', compare OE nigun

sjonge 'to sing', compare Go siggwan

tsjok 'thick' < Gmc *thekw(i)a-

An important difference is that the $w$-element is positioned in the next syllable, so $w$ and the preceding vowel can never form a unity. But I will not dwell upon back-mutation any longer; for Old Frisian, the subject was taken up again by Dirk Boutkan. ${ }^{19}$ Nor will I pay attention here to the Old Frisian diphthong io, from $\mathrm{Gmc} * e u .{ }^{20} \mathrm{I}$ just mention these points to make the reader aware that Old Frisian rising diphthongs can have several origins.

\footnotetext{
17 For an overview of the terminology, see M. L. A. I. Philippa, 'Verwarring rond de velaarumlaut: een kwestie van terminologie', $A B \ddot{a} G 17$ (1982), 113-28.

18 These examples are taken from G. Gosses, 'Stijgende diphtongen en accentverschuiving in het Friesch', Accentwisseling in de diphtongen. Bijdragen en mededelingen der Dialecten-Commissie van de Nederlandse Akademie van Wetenschappen te Amsterdam 5 (1944), 9-17, at 12.

19 Boutkan, 'On Labial Mutation and Breaking in Old Frisian'.

20 For relevant Frisian examples of that change I refer to Spenter, Vokalismus der Schiermonnikooger Mundart, ch. 3. For a broader perspective, see also K. Heeroma, 'De Gm. $e u$ in het Nederlands (II)', TNTL 65 (1947), 7-17.
} 
For Jorwert Breaking, it will be clear that the change is instigated by the glide $w$. However, what influence can be attributed to $w$ ? It has two features that may be of moment: it is back and it is round. These two features are related, in that [+ back] implicates [+ round]. In (3), the vocal nucleus of the resulting sound is a back vowel, which suggests that it has been the feature [+ back] of the glide $w$ that has caused the change. The feature [+ back] would have spread then to the left. Something like this appears to have been the idea of Damaris Nübling in her discussion of MoWFris jouwe 'give (pl.)' in the paradigm of the verb jaan 'to give' (OFris ieva), since she analyses such a form as 'eine nichtlautgesetzliche regressiv-assimilatorische Velarisierung und Labialisierung des vorangehenden $e>o(u)^{\prime} \cdot{ }^{21}$ For a verb like ieva such a regressive assimilation might hold water, since it happens to possess $/ \mathrm{j} /$ in anlaut. But the problem is that an initial $/ \mathrm{j} /$ pops up in front of the new back vowel in other cases of Jorwert Breaking. Why should this be? If it were really the case that $w$ would pass its feature [+ back] to the preceding vowel, why should that not be enough? Why does Jorwert Breaking not result in /u.w/ instead of/ju.w/, /o.w/ instead of/jo.w/, and/o.w/ instead of $/$ jo.w/?

The answer, I suspect, is to be found in the phonetics of the process. To get an idea of what is going on, it is instructive to pronounce the original falling diphthong very slowly. Then it will appear that the outcome is already found in the input. Let us take /i.w/ as an example. On careful listening it will appear that, in the transition of $i$ to $w$, a light $u$ can be heard. The transition is not abrupt, but rather, as in all connected speech, the one sound smoothly runs over into the following one. After $i$, the mouth is preparing for $w$, there is lip-rounding and the tongue is moving backwards. The result is something like $u$, which changes into $w$ in the course of speech. When we apply the same experiment to /e.w/, then we can hear a sound resembling $o$, between $e$ and $w$. No wonder, since by rounding an /e:/, and at the same time moving the tongue backwards, we end up with an /o:/. And with respect to $/ \varepsilon$.w/, this transitory sound is even more open, and hence it can be identified with $/ \mathrm{\curvearrowright} /$.

As such, these transitory sounds are of minor importance. The ordinary speaker/listener will not notice them, at most he will be aware of both parts of the diphthong, and not what subtleties are going on in the transition between the two parts. These only have a phonetic role. For the medium level, we might assign the following notation for this state of affairs: EoW. The lower-case letter only has phonetic value, and both capital letters have also phonological value. The one in boldface represents the head of the

21 D. Nübling, Prinzipien der Irregularisierung. Eine kontrastive Analyse von zehn Verben in zehn germanischen Sprachen (Tübingen, 2000), 112-15. 
cluster. However, let us imagine that things are beginning to shift, and that within the combination the prominence does not rest on the first element any longer. In that case, the transitory element would become more stressed and might take over the prominence, producing an intermediate stage symbolized here as EOW. As a result, the first element has no other choice but to weaken and become a glide, possibly as a consequence of the Glide Parameter: 'a non-head vowel is [+ high]'. ${ }^{22}$ The end result, then, is JOW.

Perhaps, we can make the emergence of $j$ plausible even without appealing to such a formal principle. It is a striking fact that one of the features of $/ \mathrm{j} /$ is that of a hiatus filler, i.e. a transitional element when a front vowel and a back vowel come together, the more so when the latter has more stress. This is nicely illustrated in the Dutch acronym EO (for Evangelische Omroep 'Evangelical Broadcast') or the name Theo. In concatenated speech these two are pronounced as [e.jo:] and [te.jo:], respectively. Now, recall that we have found that the transition of [e:] to [w] raises an $o$. In turn, we now see that the transition from [e:] to [o] can evoke a $j$. All in all, phonetically we get something like [e:jow], of course pronounced in concatenation.

Now, if [e:jow] is indeed formed, then the following scenario is conceivable. We take as a point of departure that the stress shifted to the second part, so to $o$, and hence that the first part lost its stress, at least to a large extent. Schematically, this gives EJOW. In this sequence, we can perceive two pure vocalic elements: E and $\mathbf{O}$. However, the existence of two full vowels in one syllable is precluded. Hence, the logical outcome is that the stronger of the two, which is now [o:], survives and that the weaker one, now [e.], is lost. What is left, then, is the sequence [jo:w], or, as we assumed before, phonetically possibly more correct: [jo.w]. And thus, this remnant opens with $j$.

A crucial assumption for the analysis is that the accent within the diphthong must have shifted backwards. Such a development is probably not coincidental. In Frisian there appears to exist a tendency to change falling diphthongs into rising ones. In the introductory section, I already mentioned the phenomenon of Modern Frisian Breaking. But also in the Old Frisian period the same tendency can be observed. Take for instance OFris $d u a$ 'to do', which, after shifting stress, became MoFris $d$ waan. ${ }^{23}$ Or, to turn to another category and at the same time to the front glide, take OFris liaf (cf. Du lief, G lieb, E lief), which after a shift of stress changed to ljaaf, eventually becoming MFris ljeaf and MoFris leaf. There are more examples like these; however, the effects of such instances of accent shift are less far-reaching

22 W. Visser, The Syllable in Frisian (Ljouwert, 1997), 221.

23 For comparable verbs, see H. D. Meijering, 'Die altfriesischen monosyllabischen Infinitive auf $-N$ und die Gliederung des Altfriesischen', Aspects, 336-45. 
than of Jorwert Breaking. One of the differences is that the first part of the original diphthong was already represented by a high vowel $(i$ or $u)$, and therefore it could rather easily change into a glide. A more serious difference is to be found in the second part of the original diphthong. That was not formed by a glide, but rather by a full vowel, though this vowel did not bear the main stress. It received main stress after the shift, however, and afterwards it underwent all the historical changes that affected comparable full vowels.

All in all, for Jorwert Breaking we can conclude that $w$ was the instigator of the process, but that it was not involved any further. The element was there before the process and remained afterwards. This $w$ is real, and is more than just a phonetic termination inherent to every round vowel. For instance, for those speakers of southern or eastern West Frisian dialects which have the word bedriuw 'company' as [bədrju.w], this word surely does not rhyme with doe [du] 'then', containing a short monophthong, or with the interjection boeh [bu:] 'boo!', with a long vowel.

The analysis, as applied to the mediate level/e.w/, can be transferred to the other levels /i.w/ and / $\varepsilon$.w/ as well. Nevertheless, some slight differences may possibly exist. Realization of a transitional $j$ seems easiest within $i . w$. The reason is, of course, that $i$ is phonetically closest to $j$. But the situation with respect to $\mathcal{\varepsilon}$. $w$ is different, as in the transition of $\mathcal{\varepsilon}$ to intermediate 0 an intermediate $j$ is far from conspicuous. Naturally, this can be related to the greater degree of opening of $/ \varepsilon /$ and $/ \mathrm{J} /$, in which environment the formation of $j$ is far more difficult. No doubt, the situation with respect to $e . w$ can be situated between these two extremes. That $j$ is easier to be formed after /e:/ than after $/ \varepsilon$ :/ can also be heard from these monophthongs themselves, at least in Modern West Frisian. After/e:/, a $j$-like ending always shows up; for this reason the sound may be characterized as a kind of diphthong in the phonetic sense. In contrast, the pronunciation of $/ \varepsilon$ :/ is far closer to that of a real monophthong.

It is possible that differences in the emergence of $j$ have repercussions for the emergence of Jorwert Breaking itself. The phenomenon of Jorwert Breaking does not occur very frequently, it seems, but, as we will see in the next section, when it does, then mostly at the highest level, i.e. i.w $>$ ju.w. Outside Frisian, I have not come across the transition $e . w>$ jo.w, nor $\varepsilon . w>$ jo.w. However, to the best of my knowledge, the occurrence of the phenomenon across the world's languages has never been investigated, so it is conceivable that there are other languages that exhibit the process at the lower levels too. It would be interesting if my idea turns out to be true, namely that the phenomenon is more frequent at the higher levels, and that the hierarchy manifests itself in such a way that if a language features the phenomenon at a lower level, then it will also exhibit it at higher level(s). Of course, this 
hypothesis can only be tested if the language in question has the relevant vowels in its phonological system. This hierarchy also predicts that the breaking of $\varepsilon . w>j 0 . w$ is the most difficult to realize. It will become clear in section 4 that Frisian itself may provide a direct illustration for this hypothesis.

As noted at the outset, the phenomenon of Jorwert Breaking has not gone unnoticed in Frisian linguistics, and there have been attempts of an analysis before. Already in the first publication which mentions the phenomenon, Buitenrust Hettema suggested that a shift of stress was involved; he also assumed an insertion of $u$ before $w \cdot{ }^{24}$ However, this insertion is not motivated phonetically, but mainly for reasons of orthography, it seems. The insertion of $u$, regardless of the quality of the preceding sound, is repeated by many authors. ${ }^{25}$ Problematic is also the emergence of initial $/ \mathrm{j} /$. Buitenrust Hettema simply assumed a development $e>i>j$, and Siebs suggests a 'spaltung des $\hat{e}$ und vocalisierung des $b$,- zu iou?', both without motivation. ${ }^{26} \mathrm{~A}$ more plausible explanation for the emergence of $/ j /$ is offered by Van Helten. ${ }^{27}$ If I interpret him well, van Helten suggests that the transition of a falling into a rising diphthong is performed at the highest level, so in /iu/. The change $i>j$ is indeed a small one. This analysis has found general acceptance in the literature, also for the transition at the lower level(s) ${ }^{28}$ The effect is that in order to perform the change, the falling diphthong first has to be raised to $/ \mathrm{iu} /$. Then, at that level, the shift to a rising diphthong has to take place, which subsequently lowers again. This analysis has some obvious disadvantages. First, in contrast to my analysis, the change is not a direct one. Second, the raising (and lowering) is unmotivated. At best, it is connected to the general Frisian raising of /e:/ > /i.ə/; but for $/ \varepsilon$ :/ such a raising to the highest level is problematic. ${ }^{29}$ However, the most serious objection that can be raised against such an analysis is that what once went up must also come down again. Assuming that all transitions of a falling diphthong into a rising one were performed within/iu/, how could a speaker

24 F. Buitenrust Hettema, Bijdragen tot het Oudfriesch Woordenboek (Leiden, 1888), 64. Likewise, van Helten, 'Zur Lexicologie und Grammatik des Altwestfriesischen', passim.

25 E.g. D. Boutkan, 'Phonology and Orthographic System of Old Frisian', Handbuch / Handbook, 613-20, at 617.

26 Siebs, Zur Geschichte der englisch-friesischen Sprache, 262.

27 Van Helten, 'Zur Lexicologie und Grammatik des Altwestfriesischen', passim.

28 See, most recently, Hoekstra, 'An Outline History of West Frisian'.

29 Explicitly in M. J. van der Meer, Fryske offliedkinde mei foarbylden. Foardracht hâlden for de Fryske Fakânsje-Kursus to Ljouwert de 3de fen Rispmoanne 1929 (Snits, 1929), and W. J. Buma, 'Wurdsneuperijen. 54. Nijfrysk greauwen en grevel', UW 24 (1975), 55-59. 
of Old Frisian know that in the one case he had to keep the output at the highest level, and in the other case he had to lower it to /jo.w/, or even further to /jo.w/? In sum, the bad motivation for the emergence of intitial $/ \mathrm{j} /$ and the arbitrariness between input and output of the process are serious flaws of this and previous analyses. Other details could be criticized as well, but reasons of space prevent me from discussing them here. ${ }^{30}$

\section{EVIDENCE (I): THE SOUNDS}

Up till now, the analysis has been a fairly theoretical construct, so the time has come to provide some tangible evidence. Firstly, I will give some direct evidence, and then turn to earlier stages in the language.

The most striking element in my analysis is that it predicts that in Jorwert Breaking vowel height is constant, compare the schema in (3). The first indication for a constant vowel height can be destilled from a simple phonetic experiment. If one slowly tries to accomplish Jorwert Breaking orally, then it will appear that the simplest way to realize this is by remaining at the same height. So, the change of $/ \mathrm{i} . \mathrm{w} /$ to $/ \mathrm{ju}$.w/ is the easiest one. A potential conversion from $/$ i.w/ to $/$ jo.w/ requires much more effort, and even more so the change from /i.w/ to /jo.w/. The reverse is also true. So, /E.w/ is most easily transformed into /jo.w/, whilst a change into /ju.w/ would feel quite unnatural.

An example of how easy the transition can be accomplished is the word sleau 'lethargic'. I think I picked up the pronunciation [sle.w] from my home language, but I guess that nowadays it is more often [sljo.w]. However, potential varieties such as [sli.w], [sle.w], [slju.w] or [sljo.w] are absolutely out of order. But within the same vowel height there is an easy and smooth transition. This makes it also possible that within the falling diphthong, on its way to its final goal, the first element can already prepare for rounding. ${ }^{31}$

To a certain extent, it can also be perceived in other languages that Jorwert Breaking occurs in one and the same vowel height. One source is the dialect of the Frisian island of Schiermonnikoog. Although definitely Frisian, this dialect differs considerably from varieties of Frisian spoken on the mainland. In the first printed texts of the Schiermonnikoog dialect, we see the spellings jieoewer for modern ieuwr [i.wr] 'over', Bjuer for modern bieuwr [bi.wr] 'farmer' and djuesen for modern dieuwzen [di.wzən] 'thousand' ${ }^{32}$ At the beginning of the twentieth century, the pronunciation of

30 For a comprehensive account, see my, 'Jorwertbrekking', section 4.

31 For instance, a notation $/ \mathrm{yu} /$ is offered for words such as liuw 'lion' and bliuwe 'to stay' in Hoekstra, 'Standard West Frisian', 84.

32 See J. H. Halbertsma, 'Vertaling van een paar plaatsen uit het nieuwe testament in de tongval van Schiermonnikoog', J. H. Halbertsma, Hulde aan Gysbert Japiks, tweede stuk (Leeuwarden, 1827), 165-68. 
present-day hieuwn [hi.wn] 'dog' was hju.n. ${ }^{33}$ Fokkema observes for /i.w/: 'Deze tweeklank is soms stijgend en klinkt dan als $j u$ ' ${ }^{34}$ From a recent inquiry, I learned that today the diphthong /i.w/ is only falling, but this material teaches us nevertheless that once it could easily be converted into a rising /ju.w/. However, in the Schiermonnikoog dialect I did not come across a conversion at lower levels, i.e. into /jo.w/ or /jo.w/. It is also worth noting that the Schiermonnikoog examples are pronounced with a high back vowel in their mainland Frisian counterparts, and thus do not constitute a possible input for Jorwert Breaking there.

In English, we can observe something similar. Words such as new or ewe are pronounced as [nju:] and [ju:]. Roger Lass dates this 'Jorwert Breaking' back to the seventeenth century, so at a time when the former diphthong /eu/ (in Lass's notation) was already raised to $/ \mathrm{iu} / .{ }^{35}$ The fact that we particularly observe Jorwert Breaking of /i.w/ in the Schiermonnikoog dialect and in English might not be a coincidence, as I have argued in the preceding section.

If Jorwert Breaking can be pursued so easily as argued above, and if it is sometimes not easy either to obtain a clear perceptual difference between input and outcome, then it may not come as a surprise that there can be a great deal of variation. In the Old Frisian sources, forms with and without Jorwert Breaking sometimes act together. It also occurs that words that exhibited Jorwert Breaking in Old Frisian lost the feature in later times. Miedema draws attention to the co-occurrence of forms with a rising and a falling diphthong in Old Frisian, but this phenomenon can be observed in later times too. ${ }^{36}$ His explanation that spelling conventions have a role to play may well be true, but at the same time it should not necessarily be the whole truth in light of the phonetic uncertainty just sketched.

The fact that Jorwert Breaking could easily come but also easily go makes one somewhat suspicious about the central message of Miedema's inaugural lecture Van York naar Jorwerd of 1966. Miedema observes that in the early Middle Ages maritime Frisians and Vikings entertained intensive contacts. Furthermore, he claims that Old Norse also exhibited Jorwert Breaking and concludes that the Vikings must have exported the phenomenon to Frisia. He mentions the place-name York (from Ever-vik)

33 According to L. P. H. Eijkman, Phonetische beschrijving van de klanken der Schiermonnikoogsche taal (Amsterdam, 1925), 30.

34 'Sometimes, this diphthong is rising, and then it sounds as ju', D. Fokkema, Beknopte spraakkunst van het Schiermonnikoogs (Leeuwarden, 1969), 10.

35 R. Lass, 'Phonology and Morphology', The Cambridge History of the English Language, vol. III: 1476-1776, ed. R. Lass (Cambridge, 1999) 56-186, at 99.

36 See Miedema, Van York naar Jorwerd, 12, and H. T. J. Miedema, 'Problemen met het Friese credo', Taal en Tongval 25 (1973), 33-47, at 36-38. 
and the name of the Frisian village Jorwert (from Ever-werd) as typical examples. However, the problem with such a theory, especially when the phenomena are situated in pre-history, is that its validity is hard to prove. At best, one can assume a certain plausibility, but nevertheless doubts can be raised against Miedema's position. It can always be questioned how serious and frequent such contacts with speakers of Norse actually were - according to Dirk Blok they should not be estimated too highly. ${ }^{37}$ This notwithstanding, from the kind of language contact involved, it can be predicted that this must have resulted in borrowing of lexical material rather than in the imposition of grammatical features. However, even the quantity of shared words exhibiting Jorwert Breaking provided by Miedema is not very impressive. Miedema overlooked the obvious possibility that the change could emerge within the Frisian language itself. As we have seen above, Jorwert Breaking fell on fertile soil, since as a result of the weakening of $v$ it can be predicted so many words could act as possible input. I am not alone in my doubts about Old Norse as a cause of Frisian Jorwert Breaking: neither Dietrich Hofmann nor Karel Gildemacher believe the thesis, nor does Blok, who observes the extended lapse between the time when the shift manifested itself in York (ninth century) and Jorwerd (fourteenth century). ${ }^{38}$

\section{EVIDENCE (II): THE WORDS}

\subsection{Introduction}

I would now like to turn to the historical evidence in Frisian. It is my aim to present all the words that have undergone Jorwert Breaking. Of course it is important to present as much evidence concerning the phenomenon as possible, especially as these data can support the analysis presented in section 2.

The compilation of the list has not been without difficulties. Our reconstructions of former forms and situations cannot be more than theoretical concepts; they need not necessarily correspond with the reality of the past. A typical example is the uncertainty about both long $e$ 's as discussed in section 2. Furthermore, it cannot be assumed in advance that Jorwert Breaking took place at one point in history. Furthermore, a complicating factor is that there have been all kinds of sound changes which may have disturbed the input and also the output of the process. For instance, in Frisian, lengthening of short /a/ instigated a series of raisings: original long /a:/ raised to $/ \varepsilon: /$, original long $/ \varepsilon: /$ raised to /e:/ or even /i.ə/, and finally former /e:/

37 D. P. Blok, 'De Wikingen in Friesland', Naamkunde 10 (1978), 25-47.

38 D. Hofmann, 'Thor, "Donnerstag" und "Donner" in Friesland', D. Hofmann, Gesammelte Schriften II, 366-75, at 371; K. F. Gildemacher, 'West Frisian Place Names', Handbuch / Handbook, 155-70, at 167; Blok, 'De Wikingen in Friesland', 45. 
changed to /i.ə/. ${ }^{39}$ Moreover, there can be dialectical differences, and those of former centuries are often unknown to us. Most additional changes come up in the course of the following discussion. One feature I already want to mention here is the deletion of initial $/ \mathrm{j} /$ of the broken cluster. For one thing, this is part of a much broader tendency, especially in the south-western regions of the province, and then especially after $r$ and $l{ }^{40}$ So, the preterite form bleau/bljo.w/ of the verb bliuwe 'to remain' became/blo.w/. However, this $j$ was sometimes not written also in Old Frisian times, for example in $o p$ grouwa 'to dig up' in Codex Aysma. ${ }^{41}$ This observation brings us to the issue of unreliable spellings.

It has been noted that both open and closed $e$ are not kept apart in Old Frisian orthography. As for the digraph $<\mathrm{ou}>$, it could represent $/ \mathrm{o}$.w/, but also /o:/ or its diphthongized product (/o.w/), and maybe even $/ \mathrm{u}(:) /{ }^{42}$ And what about a spelling like joegh 'eternal'? Miedema supposes a pronunciation [ju(:)x] but, in my opinion, [jo:x] is equally plausible. ${ }^{43}$ To give one more example: in the Old Frisian spelling iuw the initial $i$ may indicate $/ \mathrm{j} /$, and in this case we are concerned with a broken sound. But it could just as well stand for $/ \mathrm{i} /$, and then it represents the first part of a falling diphthong.

As mentioned previously, the primary purpose of the present account of Jorwert Breaking in Frisian is to give support to the hypothesis of constant vowel height, and its arrangement follows from this perspective. Of the words involved, I just offer the basic forms - compounds and derivations are implicated. The list is not restricted to Old Frisian per se; for a proper view at the phenomenon it seems appropriate to take a wider perspective. In fact, the picture is quite diverse. Some instances of Jorwert Breaking only seem to show up for the relevant word in the Old Frisian period, e.g. forms like op grouwa and nouwa. Since Old Frisian sources are rather scarce, there are also younger forms that have not come to us from medieval sources, but many of them have probably existed for a longer time. And of course, many forms show Jorwert Breaking in the whole period from Old to Modern Frisian.

39 See A. Versloot, 'Aldwesterlauwersk Frysk /e:/', IB 53 (1991), 71-96.

40 See, for instance, G. van der Meer, 'Toppenhúster konsonantyske bigjingroepen', UW 19 (1970), 39-43.

41 W. L. van Helten, 'Zur Lexicologie und Grammatik des Altwestfriesischen', 360, offers the writings nowa and nouwa 'nephew', where some letter $j$ or $i$ was to be expected.

42 A nice indication of possible uncertainty in this respect is indicated in the overview in A. Feitsma, De autografemen in het werk van Gysbert Japicx. Een verkennend grafematisch onderzoek naar de taal van Gysbert Japicx en een bijdrage tot de friese spellinggeschiedenis (Leeuwarden, 1974), 448-51 and 482-90.

43 H. T. J. Miedema, 'Iets over A. Spenter (1926-1977) en de etymologie van Fries slûch "slaperich" en stjûch "koppig", Taal en Tongval 32 (1982), 212-24, at 219. 
Although it has been my intention to be exhaustive, I am not under the illusion that the collection is complete. Especially in the rather heterogeneous field of personal names and place-names, I may well have overlooked some candidates. But also the fact that especially Old West Frisian is poorly investigated lexicographically poses a hindrance. For these reasons, I have restricted myself to those words that represent relatively clear cases.

4.2 The highest level: /i.w/ > /ju.w/

For the most closed vowel, i.e. /i(:)/, I have assumed a change from/i.w/ into /ju.w/. This change can easily be recognized:

(5)

liuw(es). According to van Helten such spellings of OFris līf 'body', found in MS Jus and in the charters, have undergone Jorwert Breaking, resulting in the pronunciation /ju.w/. ${ }^{44}$

liuwath, liuwade, liuwet. Forms from the paradigm of the verb libba 'to live', in MS Jus. ${ }^{45}$ Compare also the adjective liuwech 'lively'; Buma reinterpreted this word from the form luweth in MS Jus, on the basis of comparable lijuich in MS Roorda. ${ }^{46}$ In my opinion, both forms indicate Jorwert Breaking.

skiūd. According to Boersma, occurring in the Old Frisian charters; he makes the following remark (translated from Dutch): 'Of the verb * skivia (OIce. skifa) "to satisfy; to divide" we find the following forms of the past participle: schiwet, schiiwet, schywd, schiud, schioed in the expression schiwet ende schat "decided by arbitration". ${ }^{47}$ The latter two spellings indicate Jorwert Breaking. Hofmann, in the supplement to his revision of Holthausen's dictionary, comments on skivia 'teilen; befriedigen': 'nur Part.Prät. skīved (skived?), skēw(e)d, skiowet, skiūd $(s k \bar{u} d, s k \bar{d} d)$ u.a. Formen "entschieden". ${ }^{48}$ To me, skiūd appears to be the broken form of skived; in view of the form sküd the product of breaking could easily disappear, owing to the complex initial cluster $s k j$-. From Hofmann's examples one might conclude that among the variants there should also have been Jorwert Breaking of /e.w/ > /jo.w/. For this question, I refer to skiūd in (12) below. See also sjudden in (8).

44 Van Helten, 'Zur Lexicologie und Grammatik des Altwestfriesischen', 355.

45 Signalled by van Helten, 'Zur Lexicologie und Grammatik des Altwestfriesischen', 359; see also W. J. Buma, Vollständiges Wörterbuch zum westerlauwersschen Jus Municipale Frisonum (Leeuwarden, 1996), s.v. libba.

46 Buma, Vollständiges Wörterbuch, s.v. livich.

47 Boersma, De Friesche oorkonden, 96.

48 F. Holthausen, Altfriesisches Wörterbuch, rev. D. Hofmann (Heidelberg, 1985), 173, at 'S. 98. - 5'. 
These are the cases of a direct change of /i.w/ > ju.w/. At best, they might be supplemented by two other words from Middle and Modern Frisian, namely njoer 'angry; frightening' and sluch 'sleepy', but their derivation is problematic; moreover, plausible alternative etymologies have been offered elsewhere. ${ }^{49}$

As already noted, the regularity of Jorwert Breaking is disturbed by other phonological changes. One of these is Lowering, which caused OFris /u:/ to change to /o:/. Examples are OFris $k \bar{u}$ 'cow', compared to MoFris $k o$, and OFris skūva 'to shift, shove', which is now skowe. Jarich Hoekstra gives as a condition that the relevant sound should be in 'word-final position and hiatus', ${ }^{50}$ and this seems to be fulfilled by the relevant words involved in Jorwert Breaking. The result, then, is that the breaking product /ju.w/ changed into/jo.w/. It is tempting to assume that the heartland of this change is to be situated in the north-west, in particular since in the region north-east of the town of Harns (Dutch: Harlingen) the vowels in words like ko and skowe lowered even further to kou [ko.w] and skouwe, respectively. This further lowering seldom took place in words which were involved in Jorwert Breaking, but here it is striking that this one-stage lowering of /ju.w/ / /jo.w/ indeed covered the northern, western and central language area, and that only a small strip in the south and in the east was left unaffected, in addition to isolated places such as the Frisian islands and the fishing villages of Peazens and Moddergat in the north-east.

The awkward effect of this lowering is that its results interfere with the outcome of Jorwert Breaking one level lower, i.e. /e.w/ > /jo.w/. Nevertheless, there are some ways of distinguishing the two. This can be done on the basis of etymology, and dialectal varieties can often be found where the old /ju.w/-outcome is still alive. Here follow the words in which Lowering has been active:

\section{(6)}

bliuwe etc. This Modern Frisian verb, 'to remain', was OFris b(i)līva. According to Hof it has become /bljuwə/ in the south and along the eastern border of the language area ${ }^{51}$ Hof is of the opinion - and I wholeheartedly agree - that the form /bljowə/ is a later development. Indeed, none of the Old Frisian forms of this verb assembled in Vries' study exhibits an $\langle 0\rangle .^{52}$ Nor is this to be observed in the writings of the

\footnotetext{
49 For further discussion, see my 'Jorwertbrekking', 288-89.

50 Hoekstra, 'An Outline History of West Frisian', 725.

51 J. J. Hof, Friesche dialectgeographie (The Hague, 1933), 58-60.

52 O. Vries, 'Zu einem Wörterbuch der altfriesischen Urkundensprache?', Aspects, 483-94.
} 
seventeenth-century poet Gysbert Japicx. ${ }^{53}$ The Frisian islands, together with Peazens and Moddergat on the mainland, still have /ju.w/. This sound is not only observed in the infinitive but also in the forms of the present tense. There are several verbs which behaves exactly like bliuwe: driuwe, riuwe, skriuwe, triuwe, wiuwe, wriuwe and, in all probability, also kliuwe.

Diuwke. Female form of the personal name Dieuwe from Diet $+\operatorname{war}(d) .{ }^{54}$ Variants of this name abound. Diuwke itself is pronounced as [djukə], but also as [djo:kə].

driuwe, OFris driva 'to drive'. For further information, cf. bliuwe above. $J u w$. According to Winkler 'from the common Germanic [personal] name Ivo, which in Friesland also occurs as Ive, Iwe' (my translation).$^{55}$ This name occurs in a great many varieties, not only in spelling but also in pronunciation. The vowel /u./ could lower to /o./, but sometimes even further to $/ \mathrm{J} . \mathrm{w} /$, at least in the opinion of Winkler, who relates presentday names such as Jouke, Joute, Jouwsma, Joustra, Jouta or Joukema to this etymon. However, for this last series a different interpretation is available, see under Jouke in (11).

kliuwe, OFris klīva 'to climb'. For further information, cf. bliuwe above.

liuweria (OFris) 'to deliver'. Van Helten suggests Jorwert Breaking in this case ${ }^{56} W F T,{ }^{57}$ s.v. leverje, has a secondary entry lieuwerje and offers albeit with a question mark - a broken pronunciation for this variant. The same holds for the secondary entry leauwerje, but then with pronunciation [ljo.]. However, it cannot be ruled out that this last form is a direct result of the Jorwert Breaking of /e.w/. See also leauwerje in (12), in section 4.4 .

riuwe '(hay) rake'. MoDu rijf points to an earlier /i:/, so that we can posit OFris *hriva and *hrive. ${ }^{58}$ According to Hof's dialect survey, the word occurs only in the east, as a result of lexical pressure from the synonym harke. The south-east has /rju.wə/, the north-east /rjo.wə/. ${ }^{59}$

53 See W. L. Brandsma, Het werkwoord bij Gysbert Japicx (Assen, 1936).

54 J. van der Schaar, Prisma voornamen, rev. D. Gerritzen (Utrecht, 2002), 109.

55 J. Winkler, Friesche Naamlijst (Onomasticon Frisicum) (Leeuwarden, 1898), 204.

56 Van Helten, 'Zur Lexicologie und Grammatik des Altwestfriesischen', 362.

57 Wurdboek fan de Fryske Taal, ed. K. Van der Veen et al. (Leeuwarden, 1984-..). Henceforth WFT.

58 See, respectively, van Helten, 'Zur Lexicologie und Grammatik des Altwestfriesischen', 355, and N. Århammar, 'Zur Rekonstruktion des altfriesischen Lexikons mit Hilfe der neufriesischen Dialekte', Philologia Frisica anno 1988 (Leeuwarden, 1989) 94-128, at 98. Kloosterman, Het vocalisme der beklemtoonde lettergrepen van den Metslawierschen tongval, 60, points to ON hrifa 'rake' which makes a reconstruction with $*_{\bar{\imath}}$ more likely.

59 Hof, Friesche dialectgeographie, 191. 
Sieuwke. According to Van der Schaar and Gerritzen, this personal name has the same origin as Sjoerd, ${ }^{60}$ see below under (9). It is broken to [sjukə], but also lowered to [sjo:kə].

skriuwe, OFris skriva 'to write'. For further information, cf. bliuwe above. triuwe 'to throw'. Miedema relates this verb to ON prifa 'to take, catch' and reconstructs an Old Frisian form ${ }^{*}$ thriv $v a{ }^{61}$ For more information, cf. bliuwe above.

wiuwe 'to wave'. Middle Dutch knew a form wiven ${ }^{62}$ The Old Frisian cognate will have been *wivva. For more information, cf. bliuwe above.

Wiuwert. For this place-name, van Berkel and Samplonius mention an early form Wywerth (1370) ${ }^{63}$ Today the pronunciation is [vju.wət], which is also lowered to [vjo.wət].

wriuwe 'to rub'. In view of MDu wriven, the Old Frisian form will have been *wriva, a form also assumed by Kloosterman. ${ }^{64}$ For more information, cf. bliuwe above.

The verb priuwe 'to taste' constitutes a small problem. Van Helten assumed an older form *prêva, ${ }^{65}$ which is in accordance with the northern form 'prI.əuwə', mentioned by Hof, ${ }^{66}$ hence with $v$-vocalization, but without Jorwert Breaking. However, according to Hof, the word acts like bliuwe etc. in the other regions. Analogy could be at play here, and then the word does not fit well in the category discussed here. But it may also be the case that former /e:/ took part in the raising to /i:/ before it entered Jorwert Breaking.

Lowering of the broken product is one possibility for a later development. Another is palatalization. The nuclear vowel of the broken diphthong is then fronted, thereby keeping its rounded character. ${ }^{67}$ Without doubt, the instigator of this fronting is the initial $/ \mathrm{j} /$, it being a front element, too. Note also that $/ \mathrm{j} /$ often deleted after fronting the vowel. As was the case with Lowering, this fronting is part of a wider process in which the products of

60 Van der Schaar, Prisma voornamen, 354.

${ }^{61}$ H. T. J. Miedema, 'Fries triuwe (Oudnoord thrifa) en trytza, twee woorden voor "duwen, drukken", Taal en Tongval 31 (1979), 56-61, at 56-57.

${ }^{62}$ J. Verdam, Middelnederlandsch Handwoordenboek, rev. C. H. Ebbinge Wubben (The Hague, 1932), s.v. weiven.

${ }_{63}$ G. van Berkel and K. Samplonius, Nederlandse plaatsnamen. De herkomst en betekenis van onze plaatsnamen (Utrecht, 1995), 259.

${ }^{64}$ Kloosterman, Het vocalisme der beklemtoonde lettergrepen van den Metslawierschen tongval, 60 .

65 Van Helten, 'Zur Lexicologie und Grammatik des Altwestfriesischen', 356. Likewise, Spenter, Vokalismus der Schiermonnikooger Mundart, 305.

66 Hof, Friesche dialectgeographie, 58.

67 Within the scope of Jorwert Breaking, particular attention to this feature was called by Gosses, 'Snjeon'. 
Jorwert Breaking were simply absorbed. Hof provides beautiful data, and he already points to $j$ as the instigator. ${ }^{68}$ From this data one can conclude that such fronting only took place after complex initial clusters, i.e. if there is at least one more consonant before $j$. Apparently, as a consequence of this complexity, there was a need for simplification which was accomplished by way of adjusting the following back vowel to $j$. So, this condition might explain why no palatalization took place in MoFris jûn 'evening', with its simple onset, in contrast to sneon 'Saturday', with its complex initial cluster $s n j-$, although both possessed the same element joon (< evend). However, this is an example of fronting of /o(:)/, which will be discussed in more detail below.

Palatalization at a higher level, i.e. fronting of $/ \mathrm{u}(:) /$, is not to be excluded out of hand, either. With constant vowel height, something like /(j) $\ddot{\mathrm{u}}(:) /$ is to be expected. Indeed, Hoekstra observes [skr(j)ü.wə] as a possible presentday pronunciation of skriuwe 'to write'. ${ }^{69}$ And if it were a solid example of Jorwert Breaking, Gysbert Japix's spelling njuer (17th c.) might be another case, but we have already questioned whether the word njoer underwent Jorwert Breaking at all. So, a better historical example might be:

(7)

Ruerd. Personal name, from Rieuwert..$^{70}$ This form must have undergone Jorwert Breaking, fronting and $j$-deletion.

However, it is striking that in most of the relevant cases, especially in environments where shortening may occur, it is not the expected / $\ddot{\mathrm{u}} /$ that emerges, but rather short /ö/. This lower outcome may be explained by assuming that these words were first involved in the lowering of /ju.w/ to /jo.w/. Hence, these words also came into the reach of a different level of Jorwert Breaking, and so added to the complicated picture:

(8)

rju 'much'. Compare MDu/MLG rive 'abundant' and MoE rife. Hof reports to have heard the word spoken at two different vowel heights: /rjö/ and /rü.ə/.

sjudden 'flax waste'. According to Hoekema from OFris skiv-, from the verb skivia 'to divide' or from the adjective skif 'parted' plus a suffix -(i)the. ${ }^{71}$ Compare $\mathrm{MoDu}$ vlasscheef 'piece of the bark of flax'. After Jorwert

\footnotetext{
68 Hof, Friesche dialectgeographie, 238-42.

69 Hoekstra, 'An Outline History of West Frisian', 727.

70 Van der Schaar and Gerritzen, Prisma voornamen, 340.

71 T. Hoekema, 'It Skylger wurd sjudden "bern”, $U W 17$ (1968), 71-72.
} 
Breaking, the word must have been lowered, before undergoing palatalization. See also skiüd in (5) and skiōd in (12).

stjurje 'to congeal, clot'. According to Miedema from stiverje 'to become stiff. ${ }^{72}$ After Jorwert Breaking, one would expect this to change to /stju.ərjə/. This form must later have undergone Lowering and Fronting.

Words having two variants, one with palatalization and one without, are also found:

(9)

Sjoerd, male personal name, according to Miedema from Sieuwerd (< (*)Sigiward $).{ }^{73}$ The name has a female counterpart in Sjoerdsje. For the female form, Winkler also mentions the palatalized variants Sjutsje and Sjuurdtje, Sjuutje (the last two in Dutch spelling). ${ }^{74}$

stjûch 'headstrong, stubborn'. This adjective is now obsolete, but was still current before 1800. Only in the conservative dialect of Hylpen (Dutch: Hindeloopen) does the non-broken form stiuwch 'stiff' still exist. Although there have been other etymological suggestions, a derivation of stivich from stiif 'stiff' plus suffix -ich is most plausible. Miedema mentions the palatalized form stjuch /stjöx/ found in the writings of the early twentieth-century dialectologist J. J. Hof. ${ }^{75}$ Another variant, steuch /stö:x/, could possibly be interpreted as a result of fronting (plus $j$ deletion) as well. ${ }^{76}$

In conclusion, it appears that Jorwert Breaking at the highest level holds up to the expectation that /i.w/ changes to /ju.w/, so retaining its vowel height. However, the outcome of the process is disturbed in many places, due to secondary processes such as Lowering and Fronting.

\subsection{The lowest level: $\varepsilon . w>$ jo.w}

As discussed in section 2, we may assume, albeit with some provisos, that there existed two $\bar{e}$ 's, a closed one and an open one. It has been my contention that Jorwert Breaking of the open variety results in /jo.w/. As stated before, complicating is the fact that the late Old Frisian period saw a series of raisings, so that words with previous long /a:/ also came into the

\footnotetext{
2 Miedema, Van York naar Jorwerd, 12.

Ibid.

Winkler, Friesche Naamlijst, 349.

Miedema, 'Iets over A. Spenter (1926-1977)', 212-24.

76 This word has various intricacies; for a more detailed discussion, see Dyk, 'Jorwertbrekking', 292-93.
} 
scope of the rule. Be that as it may, I think that the following words are candidates to have undergone Jorwert Breaking at the lowest level:

(10)

jouwe (OFris), from ēwa 'law'. ${ }^{77}$ The Old Frisian Wedding Speeches have the form jowe. ${ }^{78}$

liouwen (OFris) 'scale, dish'. In MS Jus, it is also spelled as liowen and, without Jorwert Breaking, as lewen. Middle Dutch and Middle Low German have loven. Holthausen, in his Friesisches Wörterbuch, gives the notation lêven, which points to $/ \varepsilon: /$.

liôwa (OFris), Buma gives the meaning 'hinterlassen', ${ }^{79}$ compare $\mathrm{MoE}$ to leave. Old Frisian also knows lêva. MS Jus has forms with louw- and liow -. Van Helten offers the derivation bilyowa 'gewähren; einen oder etwas bleiben lassen, von einem oder etwas scheiden' ${ }^{80}$

However, not only words with original long $/ \varepsilon: /$ are qualified for Jorwert Breaking at the lowest level. Short $/ \mathcal{\varepsilon} /$ occurred before original $v$ as well. When $v$ vocalized, then without doubt short $/ \varepsilon /$ will have lenghtened in the subsequent diphthongization process, resulting in $/ \varepsilon$.w/. The next words are representative:

(11)

hjouwer 'oat', not recorded for Old Frisian. According to Spenter from Gmc * $a$ with 'Tonerhöhung' ('Fronting'), so presumably resulting in $/ \varepsilon / .{ }^{81}$ Hoekstra reconstructs OFris *hevere. ${ }^{82}$

Jorwert, place-name, from Ever-werd. After Jorwert Breaking had taken place, Miedema assumes a form Jouwer- ${ }^{83}$ Then, contraction resulted in /jor/-. According to Winkler, the element Ever- was also prone to breaking in other name types. ${ }^{84}$ De Vries mentions that the ev-cluster was retained in the former Frisian areas east of the river Lauwers. ${ }^{85}$

\footnotetext{
77 Holthausen, Altfriesisches Wörterbuch, ed. Hofmann, 23 and 156.

78 W. J. Buma, Aldfryske houlikstaspraken. Mei ynlieding, oantekeningen, nammelist, wurdboek en in Ingelske gearfetting (Assen, 1957), 61.

79 Buma, Vollständiges Wörterbuch, 183.

80 Van Helten, 'Zur Lexicologie und Grammatik des Altwestfriesischen', 256-57.

81 Spenter, Vokalismus der Schiermonnikooger Mundart, 313.

82 Hoekstra, 'Iampck ist en iamcker wirtet mecke', 7.

83 H. T. J. Miedema, 'Van Dublin naar Dokkum. Oudnoord Jarl "dux", Oudfries Jarla en de mogelijkheid van oudnoorse relicten in het Oudfries', Naamkunde 10 (1978), $48-80$, at 55.

84 Winkler, Friesche Naamlijst, 55.

85 W. de Vries, Friese persoonsnamen (Assen, 1952), 66.
} 
Jouke, personal name, according to Miedema and Hoekstra from Gěveke, without breaking still current in the personal name Geveke.$^{86}$ For a different opinion on the derivation of the name Jouke, see Juw in (6) (section 4.2).

Jouswert, place-name, from *Geves-würði according to Miedema, who also claims that the first element is found in the place-names Jousterp and Jouswier, and in Joeswerd in the neighbouring province of Groningen ${ }^{87}$ jouel (OFris). Holthausen lists evel 'herd', but according to Hofmann the word occurs only in the expression en jouel gān ' (jmdm.) sein Eigentum gegen lebenslänglichen Unterhalt übertragen' and in the compound jouel-bref 'Eigentumsübertragungsurkunde' ['charter recording transfer of property'] ${ }^{88}$ Breaking to jou- may occur directly on the basis of the combination $/ \varepsilon /+/ \mathrm{w} /$.

jout, jouwe, present tense forms of MoFris jaan 'to give', in Old Frisian with a stem jev-, from jeva. Jorwert Breaking of short $/ \varepsilon /+/ \mathrm{w} /$ directly results in jou-.

jouwe (OFris) 'gift', from jewe, so from $/ \varepsilon /+/ \mathrm{w} /$. In MS Jus mostly spelled as jouw-, once as jow-. The broken form also occurs in an East Old Frisian document, but Bremmer has demonstrated that the text must be of Old West Frisian descent. ${ }^{89}$

De Jouwer, Gysseling mentions the form ter Heuwera for this place name, and assumes an older ${ }^{*}$ Gevaro.${ }^{90}$ If the latter has short $/ \varepsilon /$, then Jorwert Breaking to /jo.w/- is plausible. Arjen Versloot (personal communication) draws my attention to the non-broken place name Jever in Rüstringen, formerly Frisian, in Germany.

jouwinge (OFris) noun, interpreted as 'Ausübung, gewohntes Verfahren/ Handeln', ${ }^{91}$ either from *evinge (Hofmann) or from jevinge (Holthausen's original entry). It is Hofmann who mentions the broken form jouwinge. Both spellings suggest short $/ \mathcal{E} /$ in the stem, and therefore Jorwert Breaking yields jouw-. Ahlsson has a long stem in his entry

\footnotetext{
86 Miedema, Van York naar Jorwerd, 11; Hoekstra, 'Iampck ist en iamcker wirtet mecke', 7.

87 Miedema, Van York naar Jorwerd, 11.

88 Holthausen, Altfriesisches Wörterbuch, ed. Hofmann, 155.

89 Das Emsinger Recht, ed. W. J. Buma and W. Ebel, AR 3 (Göttingen, 1967), 252; R. H. Bremmer Jr., 'Old Frisian Dialectology and the Position of the "Ommelanden"', $A$ Frisian and Germanic Miscellany. Published in Honour of Nils Arhammar on his Sixtyfifth Birthday, 7 August 1996, ed. A. Petersen and H. F. Nielsen (Odense and Bredstedt, 1996), 1-18, at 7.

90 M. Gysseling, 'De oudste Friese toponimie', Philologia Frisica anno 1969 (Groningen, 1970), 41-51, at 41.

91 Holthausen, Altfriesisches Wörterbuch, ed. Hofmann, 186.
} 
êwinge, and a broken form jōwinge.$^{92}$ The broken form also occurs in an Old East Frisian text, but see jouwe 'gift' above.

niouwa (OFris) 'nephew'. Holthausen lists neva, and from this short $/ \varepsilon /+w$ the rising diphthong jou should have emerged. This is confirmed by forms like niawen/nyawen in Jus, while Hofmann reports niawa for the codexes Aysma and Unia, and nowa for Codex Roorda. ${ }^{93}$ After the Old Frisian period the broken form disappeared (under Dutch influence?); Modern Frisian has neef.

It appears that my prediction that vowel height is constant in breaking at the lowest level, i.e. /E.w/ > /jo.w/, was right. Unfortunately, things are not always quite as straightforward as one expects and hopes. However, in order to come to grips with this problem, first it is necessary to have a look at the middle level.

4.4 The middle level: e.w $>$ jo.w

With respect to the diphthong/e.w/, I predicted that it would change to /jo.w/. This seems to be borne out by the following data:

(12)

dreauwert 'loss of working hours due to rain'. WFT gives the pronunciation /drjo.wət/, and at the same time it mentions another, unbroken, form drevert.

Gjoo, personal name. According to Jenny Visser (personal communication) used in her family as a variant of Geeuwke/ge.wkə/.

griowa (OFris) 'count', in Holthausen's dictionary entered as grēva. In Old Frisian also often spelled with ou. The variety with Jorwert Breaking did not succeed to Modern Frisian.

joegh, jōwelik (OFris) 'eternal'. Sipma assumed that the form ewelike had /e:/, on the ground of MoFris /i:vəx/; Boersma appears to have reached the same conclusion and also noted the forms jogha, joegha,joegh and yowich. ${ }^{94}$

Joo, hydronym in the south-west of Fryslân. According to Gildemacher, it derives from OFris $* \bar{e} w .^{95}$

92 L.-E. Ahlsson, Die altfriesischen Abstraktbildungen (Uppsala, 1960), 48.

93 Buma, Vollständiges Wörterbuch, 218; Hofmann, 'Die "spätgermanische" Silbenquantitätsverschiebung', 210.

94 Sipma, Fon Alra Fresena Fridome, 241; Boersma, De Friesche oorkonden, 98.

95 K. F. Gildemacher, Waternamen in Friesland (Leeuwarden, 1993), 229. 
jowel '(house)front, façade'. ${ }^{96}$ A non-broken variant geuel appears in the Snitser Recesboeken, ${ }^{97}$ with cognates in MDu ghevel (MoDu gevel) and MLG gèvel.

kreauwe (MoFris) 'to quarrel'. WFT only gives the pronunciation/krjo.wə/, but an unbroken /e.w/ occurs as well, especially in the south. Possibly there is an older form creva in Fragmentum de Literis Frisicis, an incomplete grammatical treatise published in the 1681 edition of Gysbert Japix' Rymlerije.$^{98}$ Perhaps something of the older form, and without $v$-lenition, is retained in krevelje 'to play around' in the Schiermonnikoog dialect. Van Helten assumes the older forms $*$ kreuwia $<* k^{*}$ revia. ${ }^{99}$

leauwerje /ljo.wərjə/ 'to deliver', a variant of MoFris leverje. See also liuweria in (6), section 4.2.

liuw 'lion'. Spenter reconstructs the form/le.w/ for Old Frisian; $;{ }^{100}$ according to an unpublished dialect survey of the Fryske Akademy (1993, question 12a), this pronunciation still exists today, but in the very north-east it is broken to /ljo.w/. Most of the province has /li.w/, however, presumably with regular raising from former /le.w/, compare also modern ieu 'century' and early MoFris eeuw (e) (cf. joegh above).

reau 'tools, equipment'; according to WFT generally pronounced as /rjo:/. For its etymology this dictionary points to Du gerei,gereed(schap) and G Gerät, a suggestion which on formal grounds must be seriously questioned. Alternatively, Buitenrust Hettema's assumption of OFris *rêwe is much more plausible. ${ }^{101}$ Presumably, the latter word is incorporated in the derivation birêvia in MS Jus, interpreted by Buma as '[Dutch] laden, beladen' (to load, burden') ${ }^{102}$ It is interesting to notice that this Old Frisian verb also seems to have undergone Jorwert Breaking. At least, Jus also has a variant birouwia.

skiōd (OFris), probably from earlier skewed. For more details, cf. skiūd under (5) in section 4.2 above and sjudden in (8).

\footnotetext{
6 See P. Sipma, Oudfriesche Oorkonden, OTR 2 (The Hague, 1933) II, no. 221/13 (p. 241), an original charter from the town of Workum (1485).

97 See M. Oosterhout, Snitser Recesboeken 1490-1517 (Assen, 1960), 467. I thank Henk Meijering and Oebele Vries for bringing these attestations to my attention.

98 See P. H. Breuker, It wurk fan Gysbert Japix. I. Tekst yn facsimilee (Leeuwarden, 1989), 299. However, the Old Frisian words in this treatise are not always reliable, see R. H. Bremmer Jr., 'Oer datearring, funksje en auteurskip fan de earste Fryske grammatika (1681)', Philologia Frisica anno 1990 (Leeuwarden, 1992), 9-32, at 22.

99 Van Helten, 'Zur Lexicologie und Grammatik des Altwestfriesischen', 362.

100 Spenter, Vokalismus der Schiermonnikooger Mundart, 298.

101 Buitenrust Hettema, Bijdragen tot het Oudfriesch Woordenboek, 17.

102 Buma, Vollständiges Wörterbuch, 42.
} 
skreauwe (MoFris) 'to shout', perhaps a loan from MoDu schreeuwen. WFT only mentions the pronunciation /skrjo.wə/, but according to my own observations /skre.wə/ occurs as well.

sleau 'lethargic', from OFris *sleww(e). Both the pronunciations/sle.w/ and /sljo.w/ are found. It is cognate with, e.g., Du sleeuw and E slow.

As in the highest level, fronting occurs here too, mostly in its long form, as /ö.ə/, but also shortened to /ö/. Among other forms, this palatalization can be observed in the past tense and past participle forms bleau /blö.ə/ and bleaun /blö.ən/ from the verb bliuwe 'to remain' and similar verbs. However, the situation in this instance is rather complex and will be discussed later. The same applies to kleaune in (16), which also has its particular complications. Consequently, for direct cases of fronting we are left with:

(13)

ljurk 'lark'. Århammar has argued that this word was borrowed from Middle Dutch as lêwerik. ${ }^{103}$ Next, Jorwert Breaking and some further contraction would have given *ljoork, whence modern ljurk /ljörk/ as the result of subsequent palatalization and shortening. Van Helten postulated a form with iou, ${ }^{104}$ a form which Århammar thinks is confirmed in the early seventeenth-century spelling liourck (Burmania Proverbs). But as argued above, it is not possible to draw reliable conclusions on the basis of the spelling $\langle\mathrm{ou}\rangle$.

sneon [snö.ən], from OFris sunna-evend 'Saturday'. Holthausen presents $\bar{e}$ vend, which points to /e.w/. Spenter, too, gives /e:/ as the input, which therefore yields an expected Jorwert Breaking to /jo.w/. ${ }^{105}$ Of the first element, only $s n$ - survived. After palatalization, $j$ was also deleted.

In section 4.2, in our account of Jorwert Breaking at the level of /i.w/ > /ju.w/, we saw that its product could undergo a lowering to /jo.w/. A similar lowering seems to be possible for the products of Jorwert Breaking of original /e.w/, in this case lowering resulting in /jo.w/. Again, the criterion seems to be the position in open syllable. We have already encountered an example in our account of ljurk in (13) and perhaps also in some other spellings with $\langle\mathrm{ou}\rangle$. And as before, this lowering has a wider range than

103 N. Århammar, 'Die Lerche (Alauda) im Friesischen: ein Beitrag zum Atlas Linguarum Europae. Über Inlautassibilierung, unregelmäßige Lautentwicklung und "Lehnlautungen"', Miscellanea Frisica. In nije bondel Fryske stúdzjes, ed. N. Århammar et al. (Assen 1984), 137-52, at 146.

104 Van Helten, 'Zur Lexicologie und Grammatik des Altwestfriesischen', 379.

105 Holthausen, Altfriesisches Wörterbuch, ed. Hofmann, 23; Spenter, Vokalismus der Schiermonnikooger Mundart, 314. 
solely the products of Jorwert Breaking. Already Hofmann pointed out this fact, as did Hoekstra in a subsequent article. Hoekstra mentions cases such as MoFris (Alde)hou '(old) churchyard' < howe, rouwe 'scab' < *rowe and douk 'bung' $<*$ dowik. ${ }^{106}$ And, as we have seen before, an inconvenient consequence of this lowering process is that its results match the direct results of Jorwert Breaking at one level lower. Two relevant cases are worth mentioning:

(14)

hjouw(e) (MoFris) 'dip net', cf. Du haaf, have; in Scandinavian languages also with long $a$. This vowel could have been closed /e:/ in Old Frisian; Buma assumes OFris *hêve. The breaking product/jo.w/ will have been lowered to /jo.w/. ${ }^{107}$

Ljouwert, the name of the capital of Fryslân. According to Buma from Lêwert. In Old Frisian, spellings with -ow- as well as -ouw- are found. ${ }^{108}$

However, at the mid level, a movement to a lower position is not the only possibility. Theoretically, the opposite direction is also available. And indeed, this is what has happened, at least in some instances. The condition seems to have been that the stem vowel was followed by $l$ or $n$. Again, this is part of a more general process. Examples are MoFris stoel $/$ stu.əl $/<$ OFris stōl or ModFris sûn $<$ OFris sond. Relevant for our purposes are:

(15)

jûn (MoFris) 'evening'. For Old Frisian, Holthausen lists èvend, which points to /e.w/, and also Spenter has /e:/ as input with subsequent Jorwert Breaking to /jo.w/. In the Old West Frisian manuscript Jus we find (case endings included), spellings such as iounde, ioendes, jond, iond, jonde. In Modern Frisian the form joon/jo.n/ is still found in a small area in the south-east, in the other areas it was raised to /jun/.

sjoel(-). This stem can be found in nouns and verbs designating 'to slide' or 'to drag'. According to Hoekema it should be related to an Old Frisian verb 'to slide'. ${ }^{109}$ The ordinary Old Frisian form for this meaning is skūva, but Hoekema argues that a variant skiāva must have existed, too. Later, that form must have raised to skiēva. To make things complete we have to assume that a suffix $-e l$ is also involved (Hoekema does not mention this). Then, a combination of verbal stem plus suffix would manifest itself in such Modern Frisian compounds as skevelbûgel, skevel-

106 Hofmann, 'Thor, "Donnerstag" und "Donner" in Friesland'; Hoekstra, 'Iampck ist en iamcker wirtet mecke'.

107 W. J. Buma, 'Wurdsneuperijen. 11. Hjouwe en peasjou', UW 7 (1958), 71-72.

108 Ibid.; see also Miedema, Van York naar Jorwerd, 9-10.

109 T. Hoekema, 'Sjoel(j)e; sjouwe', UW 34 (1985), 102-05, at 102. 
keatting and skevelplaat (all parts of an old-fashioned plough) and in the verb skeuvelje 'to shuffle'. Since $-k$ - can delete in the consonant cluster skj- (MoFris sjitte 'to shoot' from OFris skiāta is a case in point), application of Jorwert Breaking would result in *sjool. After raising, this form would have ended in sjoel.

Although some secondary changes were witnessed, the picture that has emerged up till now is pretty clear: Jorwert Breaking can change /e.w/ into /jo.w/. However, there are also words which distort the picture somewhat. First, some came up with original long /a:/ which in Frisian raised to $/ \varepsilon:$; here it looks as if Jorwert Breaking took place only at the higher level of/e:/:

(16)

greauwen (MoFris) 'dripping', but more relevant is E greaves, G Grieben. In the south-east this word is still without $v$-weakening (greven), but the south-west has it; moreover, most of the language area also shows Jorwert Breaking, resulting in/grjo.wən/. Spenter suggests that the word should have shown $i \bar{a}$, with subsequent deletion of its first part 'Gemäß der Regel vor Resorption der ersten Komponente des Diphthongs $i \bar{a}$ unter Verengung der zweiten Komponente zu afries. $\bar{e}{ }{ }^{110}$ If Spenter is right, then this word belongs to this sample, and not to regular (12).

kleaune (MoFris) 'ball (of wool, etc)'. According to Spenter, this word had le.w/ in Old Frisian from Gmc *eu. ${ }^{111}$ This reconstruction is confirmed by the dialect map in Van der Veen, Versloot and Rypma. ${ }^{112}$ In the north, the west and the middle of the language area fronting and deletion of $j$ changed a broken form into /klö.ən(ə)/. However, a pure, broken variety still shows up: $k l(j)$ owen. Some places in the south-east have /kli.uwən/, which form may result from analogy under influence of the bliuwe verbs, but Dutch interference from klieuwen cannot be ruled out either. Alternatively, another course of events is also conceivable: Gmc *eu showed up in Old Frisian as $i \bar{a}$, which would yield *kliāwen $;{ }^{113}$ with deletion of $j$ and raising of the stem vowel one would also arrive at/kle.wən/, and again with the same contemporary manifestations.

reaf (MoFris) 'skein'. According to Hof, in the north this word is still found without $v$-weakening: reaf/rI.əf/ $/{ }^{114}$ In the south it shows $v$-weakening, /re.w/, as well as variants with Jorwert Breaking: /rjo.w/. The northern

110 Spenter, Vokalismus der Schiermonnikooger Mundart, 296.

$111 \quad$ Ibid. 297.

112 K. F. van der Veen, A. Versloot and W. Rypma, Dialektgeografyske oantekens fan

J. J. Hof (Leeuwarden, 2001), 91.

113 W. J. Buma 'Nijfrysk greauwen en grevel', UW 24 (1975), 57-58.

114 Hof, Friesche Dialectgeographie, 55-56. 
form points to a late Old Frisian stem vowel $/ \varepsilon$ :/, from OFris $\bar{a}$, cf. Du roof. Indeed, the Woordenboek der Nederlandsche Taal offers an Old Frisian counterpart $r \bar{a} f .{ }^{115}$ Hof also observed a lowered variety/ro.w/, but this may be a remnant of the Old Frisian form after $v$-weakening and contraction.

It appears that the cases above are rather unclear; this is even more the case in the following words:

(17)

kleau 'split, crevice', kleauwe 'to split'. Du kloof and ON klauf suggest a Germanic etymon *klauf for the noun. This would have resulted in *kläf for Old Frisian. Indeed, we find klâve in Holthausen or, in Hofmanns improved edition, kla(u)wa. For the verb, van Helten assumed an early Old Frisian *kleuwa ('aus *klêva(n)'). Maybe, it is better to depart from Gmc *klaubjan, which would yield /ع:/ in Old Frisian. The modern pronunciation for both categories is $/ \mathrm{kljo.w} /$, which should have a source /kle.w/, and which still is the form in the Hylpen dialect. ${ }^{116}$

leauwe (MoFris), both noun 'belief' and verb 'to believe'. According to Miedema, the verb is the reflex of OFris levva ${ }^{117} \mathrm{He}$ points to Gothic galaubjan for the umlaut factor that brought about $\hat{e}$. One would therefore expect Jorwert Breaking to have resulted in ljouwe, and indeed this form does exist, albeit in the margins of the language area. ${ }^{118}$ Nevertheless, in the larger part of the province the pronunciation is /ljo.wə/, at first sight corresponding to the area where bliuwe etc. is pronounced as /bljo.wə/, so that analogy may have played a role here. However, modern leauwe is not only a verb, but also a noun. In Old Frisian the two were kept apart, the noun having the form lâva. It is possible therefore that /a:/ in this noun was raised as in similar cases, that it was accompanied by the corresponding verb in the $/ \varepsilon: /$-stage, and that Jorwert Breaking was applied not earlier than the /e:/-stage - a scenario comparable with what was assumed for kleauw, kleauwe above, which would explain the form /ljo.wə/ in a direct manner. The dialect variant ljouwe can be seen as the result of further lowering in open syllable, and as a form to which the other forms of the verbal paradigm adapted later.

115 Woordenboek der Nederlandsche Taal, ed. M. de Vries et al., 29 vols. (Leiden, 1882-1998), s.v. roof (II).

116 Holthausen, Altfriesisches Wörterbuch, ed. Hofmann, 58; van Helten, 'Zur Lexicologie und Grammatik des Altwestfriesischen', 361

117 H. T. J. Miedema, 'Problemen met het Friese credo', 34.

118 This can be destilled from a map in Miedema, ibid. 41, which is based on data from K. Boelens and G. van der Woude, Dialect-atlas van Friesland, Reeks Nederlandse Dialect-atlassen 15 (Antwerp, 1955). 


\subsection{The two $e$ 's revisited}

If the analysis of the last sample of words in the preceding subsection holds water, this would imply that words with original/a:/, in the course of raising, did not use the potential possibility to apply Jorwert Breaking in the stage of $/ \varepsilon: /$. This might indicate that there was an aversion towards Jorwert Breaking at the lowest level, i.e. the change $/ \varepsilon$.w $/>/$ jo.w/. Such an aversion seems to be confirmed by the following sample of words, all of which had short $e$ in their stem originally. They underwent Jorwert Breaking, but with such a result that one is compelled to conclude that they were involved in the transition /e.w/ > /jo.w/. Some of them show /o(:)/, which is difficult to explain by other means, while others show $/ \mathrm{u}(. \theta) /$ in Modern Frisian, which must be raised from an $o$-sound. Moreover, in one case we even encounter fronting to /ö.ə/ or /ö:/, which is not conceivable on the basis of/jo.w/. The following words are relevant:

(18)

gjoele, probably Middle Frisian or Late Old Frisian. Postma reports that in old inventories he had found the following words for Dutch gaffel 'gaff, fork': gyoele, guel or guele, joele, juile and jole. ${ }^{119}$ The etymological dictionaries mention gafala for Old Saxon and gafol, geafel for Old English. With fronting of short * $a$, we may assume * gevle for Old Frisian. In three of Postma's six forms $g$ is deleted before $j$, which is not uncommon in Frisian. ${ }^{120}$ I suppose that jole is the form after Jorwert Breaking, possibly also gyoele and joele, but these forms might also show raising to $u$ before l. Presumably, guel, guele and juil show influences of palatalization.

griowa, griowe (Old Frisian) 'to dig'. In his 'Berichtigungen und Nachträge', Holthausen, gives the notation greva, which points to a short stem vowel (the lemma in the original dictionary had grêva). Addition of the suffix -inge resulted in *grevinge, the base for a number of water names. ${ }^{121}$ In Grûns (< Grons) we find raising to $u$. Palatalization of the cluster/jo.w/ has resulted in Greuns. The compound Greventerp stands at the basis of the palatalized place-name Greonterp (/grö.ənterp/). ${ }^{122}$ jowen (Old Frisian) 'even', also in jowncristen 'fellow-Christian'. Van Helten also mentions the derivations onjown 'ungleich' and jowns 'gleichfalls', and Hoekstra adds two further attestations of this form in

119 O. Postma, 'Noch eat oer it wurd "tsjoele"', Fryske Plaknammen 8 (1956), 5-6.

120 H. T. J. Miedema, 'De friese voornamen Gjalt en Jelte naast fries gjalt, geld "onbevrucht"', Feestbundel aangeboden aan prof.dr. D. P. Blok, ed. J. B. Berns et al. (Hilversum, 1990), 254-60.

121 Gildemacher, Waternamen in Friesland, 271-73.

122 Gosses, 'Snjeon', 43; Miedema, Van York naar Jorwerd, 12. 
the compound allijons $<*$ alevens 'likewise'. ${ }^{123}$ The variants with Jorwert Breaking appear most frequently in Codex Roorda and in the Old Frisian charters. The problem here is MoFris jamk, which Hoekstra claimes to be derived from * evenlik. Compared to the other forms, this should have been $*$ jomk/jomk/. To arrive at jamk, Hoekstra assumes an intermediate *jowen which in the process of lowering, thanks to its open syllable, resulted in *jo.wen. Then, contraction would produce *jomk. However, since in Frisian 0 is not allowed before $m$, the vowel is lowered further to jamk. Incorporation of Jorwert Breaking of this stem into this sample is mainly based on interpreting the spellings to represent/jo.w/. If, on the other hand, this were /jo.w/, this complex could be subsumed under (11) jûn (MoFris), past participle of jaan 'to give'. The south-east still has the older form joon, so without raising. Old Frisian has ieven, with short $e^{124}$ njonken (MoFris) preposition 'beside, next to'. From *nevenlik; ${ }^{125}$ the sound [o] in the modern word points at Jorwert Breaking of /e.w/.

sjoen (MoFris), past participle of sjen 'to see'. From a root $*_{s e w V n-.}{ }^{126}$ Apparently, Jorwert Breaking resulted in a stem with /jo.w/, and afterwards the vowel was raised before final $-n$.

stjûne (MoFris) 'stem (of a ship)' For Old Frisian, Holthausen lists stevene. ${ }^{127}$ Jorwert Breaking must have changed this to /stjo.w(ə)nə/, which raised before $n$ to /stjunə/.

tiole (OFris) 'table'. Holthausen presents tefle and tevle, in addition to tiōle. ${ }^{128}$ In MS Jus, the form with Jorwert Breaking occurs most frequently, whereas teula is attested only once. According to Hoekstra, tsjoele 'square fishing net' is a modern remnant of the Old Frisian broken form; the word tsjoele also survives in field-names. ${ }^{129}$

123 Van Helten, 'Zur Lexicologie und Grammatik des Altwestfriesischen', 358; J. Hoekstra, 'In nijwesterlauwerskfryske wjergader fan Aldfrysk (hona) etsel '(hoanne)spoar', UW 48 (1999), 3-9, at 8.

${ }_{124}$ W. Steller, Abriss der altfriesischen Grammatik (Halle/S., 1928), 62.

125 T. Hoekema, 'Njonken nêst neffens', De Pompeblêdden 22 (1951), 69-70; 104; T. Hoekema, 'Njonken, tusken', De Pompeblêdden 24 (1953), 47-48; also W. J. Buma in J. L. A. Heestermans, 'Naar', 'naast', 'langs' en 'in'. Een onomasiologisch-semasiologische studie over enige voorzetsels met een locaal betekeniskenmerk in de Nederlandse dialecten en het Fries (The Hague, 1979), 74.

126 Reconstruced variously as *sewan, *gisewin, *sewun, *sewen, respectively, by van Helten, 'Zur Lexicologie und Grammatik des Altwestfriesischen', 379; J. Jacobs, 'Geschilpunten in de Oudfriesche klank- en vormleer', Leuvensche Bijdragen 4 (19001902), 125-37, at 136; Boersma, De Friesche oorkonden, 98; Gosses, 'Snjeon', 42.

127 Holthausen, Altfriesisches Wörterbuch, ed. Hofmann, 104.

128 Ibid. 109 and 176.

129 Hoekstra, 'Iampck ist en iamcker wirtet mecke', 7. See also O. Postma, 'Tyole, tyolle, tsjoele, ensfh.', Fryske Plaknammen 7 (1955), 3-4; Postma, 'Noch eat oer it wurd "tsjoele”; P. B. Winsemius, 'Tsjoele - tyole', Fryske Plaknammen 7 (1955), 4-8; P. B. 
If the words listed above have in fact undergone the transition /e.w/ $>/$ jo.w/, then one wonders how this is possible. In section 4.3, we assumed that in lengthening short $e+w$ would change in quality as little as possible, and hence would result in the diphtong $/ \varepsilon$.w/. The segment $/ \varepsilon$./ could have been part in the general tendency towards raising, which would have resulted in /e.w/. But (18) seems to contain very early examples of Jorwert Breaking, and it can be questioned whether raising had made enough progress at the time. Another possibility is that the result of lenghtening of $/ \varepsilon \mathrm{w} /$ was not /E.w/, as we assumed thus far, but /e.w/. Lengthening of $/ \varepsilon />/$ e:/ was not uncommon in West Germanic languages, cf. Dutch gebed and its plural gebeden as a clear example. In discussing lengthening in anlaut, Hoekstra also assumes a pattern / $\varepsilon />$ /e:/ for Old Frisian. ${ }^{130}$ In his view, these sounds build a natural pair for the older stages of Old Frisian. In a subsequent article, Hoekstra still assumes a three level system, both for the short and the long vowels, and the middle levels are occupied by $/ \varepsilon /$ and /e:/, respectively. ${ }^{131}$

If it could be taken for granted that the cases in (18), with original short $\varepsilon$, as a result of lengthening were involved in the Jorwert Breaking/e.w/ > /jo.w/, then one might wonder how other cases of short $\varepsilon$ plus $w$ fared. For the relevant words in (11) in section 4.3 we assumed that they obeyed the rule of $/ \varepsilon$.w/ $/>$ jo.w/, but actually this might occur one level higher without any problem, so at the level of /e.w/ > /jo.w/, since its result, thanks to the position in open syllable, is a possible input for the lowering rule, eventually ending in /jo.w/ again. By the very existence of this lowering process, it remains indecisive whether we are dealing with Jorwert Breaking at the lowest or at the middle level.

So, if in principle it is possible for words with short $e$ as a stem vowel to be eliminated in Jorwert Breaking of the lowest level, how about stems with original $/ \varepsilon$ :/? In principle, these could be eliminated, too. The cases of Jorwert Breaking in (10) all show an output/jo.w/ in open syllable, so again the route via/jo.w/ is not to be excluded out of hand. Therefore, it is to be expected that those people who doubt the existence of two kinds of $e$ in Old Frisian (cf. section 2) will not readily change their minds on the basis of the facts of Jorwert Breaking. The existence of Jorwert Breaking $/ \varepsilon$.w/ / jo.w/ cannot be proved on the basis of solid evidence.

Winsemius, 'Jitris “tyole, tsjoele"', Fryske Plaknammen 8 (1956), 7-10; J. J. Spahr van der Hoek, 'Tsjoele', Fryske Plaknammen 7 (1955), 9-16.

130 Hoekstra, 'In nijwesterlauwerskfryske wjergader', 5-6.

131 Hoekstra, 'An Outline History of West Frisian', 722. Similarly, in Boutkan, 'Phonology and Orthographic System of Old Frisian', 617, where the existence of a long $/ \varepsilon: /$ is doubted, i.e. as a consequence /e:/ would be the natural lenghtening product of $/ \varepsilon /$. 
If it indeed were the case that the lowest level of Jorwert Breaking was never there - and perhaps its 'skipping' in the admittedly rather unclear samples (16) and (17) is perhaps the strongest indication for this position then such an outcome is not totally unexpected. The prediction should be remembered from section 2 that of the three levels the lowest is the most difficult to perform. If it turned out that the transition $/ \varepsilon$.w/ $>$ /jo.w/ never took place, this might be a confirmation for the hypothesis.

It will have become clear by now that it is far from easy to make an unequivocal reconstruction for Jorwert Breaking. As an additional illustration, I shall now discuss one form, or rather a group of forms. It concerns the preterite and past participle of bliuwe 'to remain', and with it the corresponding forms of driuwe 'to drive', riuwe 'to lace', skriuwe 'to write', triuwe 'to push', wriuwe 'to rub', and also priuwe 'to taste':

(19)

bleau(wen), bleaun, etc. These preterite and participle forms of the verb bliuwe 'to remain' are pronounced as bljou [bljo.w], bljoun (also bljound or bloun) in the south, but also in the north-west. The Germanic stem vowel of the preterite singular $a i$ should have shown up as $/ \varepsilon$ :/ in Old Frisian, ${ }^{132}$ we can still observe this in the writings of the poet Gysbert Japicx (1603-1666). ${ }^{133}$ The present-day pronunciation/bli.əf/ in a small area in the north-west is compatible with that open quality. So, the southern dialectical varieties receive an explanation if we assume that the quality of the stem vowel of the preterite singular spread towards the preterite plural and the participle. However, in the major part of the province the pronuciation is /blö.ə(n)/ nowadays. This palatalized form points to /jo.w/ as input, not/jo.w/, which would have fronted to /jö.w/ or something similar. However, in Frisian such a sound does not exist, which might explain why it was raised to the sound which is closest, i.e. /ö.e/. On the other hand, it is equally possible that the difference should be traced in a change in the input. However, in this case the problem is how to arrive at alleged /e.w/. Analogy on the preterite plural or even past participle is not obvious, as originally this was $/ \mathrm{i} / .{ }^{134} \mathrm{Hence}$, it is tempting to recall the discussion about the two $e$ 's. For one thing, if the breaking product is /jo.w/, then the form /jo.w/ at the fringes of the language area could easily be accounted for by taking recourse to the lowering rule. But then we are nevertheless left with the bleaf-area in the north-west, and maybe also for a small area in the east, where Hof

132 Steller, Abriss der altfriesischen Grammatik, 59.

133 Gysbert Japicx always spelled <eau $>$ for the pronunciation just mentioned, according to Feitsma, De autografemen in het werk van Gysbert Japicx, 577.

134 Steller, Abriss der altfriesischen Grammatik, 59. 
records the pronunciation blI.ewen. In short, with the one $e$ the form bleaf is left unexplained, and with the other the derivation of the fronted form is difficult. On the basis of these facts one is inclined to assume a dialectical existence of two different ' $e$ 's already in the Old Frisian period, but it will be hard to find independent evidence for such a position.

\subsection{Summary}

In the introduction to this section, I expressed some provisos with respect to the ability to give a reconstruction of Jorwert Breaking in separate words. As to the exact interpretation of spellings as well as in the area of pronunciation one comes across lots of uncertainties that can disturb a clear view of the real course of events. In this light, it is nevertheless striking how well the hypothesized system, as it is sketched in section 2, is corroborated. In addition, it is especially important to keep an eye on subsequent processes. For instance, in some cases palatalization yields a different result than expected; in particular, the later raisings $(o:>u(:))$ and especially the lowerings $(u:>o$ : and $o:>0 . w)$ considerably disturb the outcome of Jorwert Breaking.

When we take these later processes into account, then Jorwert Breaking, as it is sketched in section 2, can be recognized quite well in the material which has passed down to us. This is most clearly the case with regard to the transition /i.w/ > ju.w/, but it can be upheld for the transition one level lower, i.e. /e.w/ / jo.w/ as well. However, much more problematic is the hypothetically presupposed transition $/ \varepsilon$.w $/>/$ jo.w $/$. The very availability of the independent lowering process $/ \mathrm{jo.w} />/ \mathrm{jo} . \mathrm{w} /$ prevents us from proving the existence of Jorwert Breaking at the lowest level, but neither can its nonexistence be proven either. However this may be, from this overview of Frisian word material the point made in section 2 still stands, namely that in Jorwert Breaking vowel height is constant.

\section{IMPLEMENTATION}

In the preceding section, an overview was given of those words in West Frisian that underwent Jorwert Breaking. Although we may assume that this list is fairly complete, it nevertheless gives a one-sided picture in that only the outcome of the process is presented. It offers no information about how the change was performed, how fast, at which time, and how many of the potential words were involved. In this section, I would like to address some of these questions.

To be sure, these questions are more readily put than answered. We are dealing here with a historical process; we have no contemporary witnesses. 
And the sources, as will be well known, are scarce. Frisian has a modest written tradition, and the diversity of text sorts is equally modest. Some words can hardly, if at all, be found in historical texts. Especially after c. 1550 the stream almost runs dry, and this situation continues for a century or so. At the very beginning of the written tradition, the Old West Frisian legal codexes provide a fair amount of linguistic material, but the repertoire is limited, and such a codex remains a relatively instantaneous exposure in itself. In comparison, the Old Frisian charters present a much more useful source for our purposes. They constitute an ongoing stream of texts, roughly from the end of the fourteenth until de middle of the sixteenth century. Moreover, all these texts are dated. Since they are bound to a certain place and are written by a certain writer, they are also important for dialectical research, although it must be admitted that the database of the charters in the Frisian institute at the University in Groningen is not equipped well enough at the present time for such special purposes. So, I leave the dialectical aspect for what it is. To be sure, research into the emergence and further development is a time consuming affair; I have left it with some random checks, which nevertheless provided enough useful data to get the beginning of a picture. ${ }^{135}$

When looking into these historical sources, it is hard to make up a consistent picture from the data. A well known example of Jorwert Breaking is MoFris jûn 'evening'. In the medieval charters, this is mostlyjond. Codex Unia, generally considered to be the most conservative Old West Frisian manuscript, still has ewend, which is consistent. However, it would be too hasty to conclude that Jorwert Breaking as a whole had settled before charters were compiled in Old Frisian.

Take the past participle of modern bliuwe 'to remain', for example. In the charters, this form does not show completed application of Jorwert Breaking - the figures never exceed two-thirds of the potential instances. Nor is it true that the cases of Jorwert Breaking typically show up at the end of the period. For instance, in the years 1503, 1519 and 1543 we still find the spelling bleven. Moreover, according to Feitsma, the seventeenth-century poet Gysbert Japix had no Jorwert Breaking in this form. ${ }^{136}$ To be sure, the preterite in an area in the north-west of Fryslân today still has the form bleaf, so also without $v$-vocalization.

135 For these random checks, I skipped the transition $i . w>j u . w$. The reason is the unreliability of the orthography. For instance, a historical spelling like iu can be interpreted in two ways, broken or unbroken. The sign $\langle\mathrm{i}\rangle$ can represent both $i$ or $j$, and the same can be said of the sign $\langle\mathbf{u}\rangle:$ both $/ \mathrm{u} /$ or the semivowel $w$ come into mind. Therefore, I confine myself to Jorwert Breaking of both ' $e$ 's.

136 Feitsma, De autografemen in het werk van Gysbert Japicx, 468. 
Could it be that jûn 'evening' underwent Jorwert Breaking so early and so completely because the breaking product/jo.w/ was reanalyzed in such a way that $j$ was no longer considered to be part of the thriphthong, but rather as the onset of the complete syllable, which would create a more common syllable structure according to a CV pattern? ${ }^{137}$ This might seem to be a plausible explanation but appears not to be supported by the facts. Take the Old Frisian etymon for MoFris ivich 'eternal', which occurs relatively frequently in the charters. Only in about $30 \%$ of the cases does it show signs of having undergone Jorwert Breaking, and its adverbial derivative with suffix -lik (jowelika, iouwelike, joulike) scores even lower. In this instance, Jorwert Breaking manifests itself most frequently in the second half of the fifteenth century, but after 1500 the relative number rapidly diminishes. This pattern matches with the modern form ivich, which shows neither Jorwert Breaking nor even $v$-weakening. Furthermore, in the charters, a loanword like eventure 'unforseen event' never shows Jorwert Breaking, but the same applies to such native words as ewen wol 'however' and ewa 'law', although, again, the relevant material is minimal.

That a word displays Jorwert Breaking in the Old Frisian period, but later stops doing so, is not an accident. Of course, I do not refer to words that vanished from the lexicon, such as jouel 'property', jouwe 'law' or jouwinge 'custom'. Also words like MoFris graaf 'count' and grave 'to dig' do not count in this respect. At least, it seems that these forms are loans from Dutch rather than continuations of their Old Frisian ancestors, whether broken or not. A word like neef 'cousin', not broken nowadays, must also be a Dutch loan, since Frisian short /e/ is not lengthened in open syllables, and the same applies to a word like even 'even, equal'.

There are even some words that never betrayed a sign of Jorwert Breaking. They include the following:

$\begin{array}{lll}\text { tsjeaf } & \text { 'thief' } & \text { pl. tsjeaven } \\ \text { skeaf } & \text { 'sheaf' } & \text { pl. skeaven } \\ \text { sleef } & \text { 'ladle' } & \text { pl. sleven } \\ \text { reef } & \text { 'reef' } & \text { pl. reven } \\ \text { stêf } & \text { 'staff' } & \text { pl. stêven } \\ \text { stiif } & \text { 'stiff' } & \text { infl. stive }\end{array}$

One might object that these words end in voiceless $f$, and hence cannot undergo $v$-vocalization. However, the right-hand column show that these

137 For example, see G. N. Clements and S. J. Keyser, CV Phonology. A Generative Theory of the Syllable (Cambridge, MA, 1985). 
words exhibit a $v$ in inflected forms; moreover, Fokkema demonstrated that final devoicing in Frisian must be of relatively recent date. ${ }^{138}$ What is more, there are also words with intervocalic $v$ which never turned into voiceless $f$, and nevertheless they show the same aberrant behaviour of not having undergone Jorwert Breaking:

$\begin{array}{ll}\text { lever } & \text { 'liver' } \\ \text { jenever } & \text { 'gin' } \\ \text { iver } & \text { 'diligence' } \\ \text { fiver } & \text { 'pond' } \\ \text { grevel } & \text { 'a little bit' } \\ \text { skevel } & \text { 'fellow' } \\ \text { swevel } & \text { 'sulphur' } \\ \text { leven } & \text { 'noise' }\end{array}$

Without doubt, this sample contains a great many loanwords. If $v$-vocalization ceased after the Old Frisian period - and it looks as if this was the case - then their present-day form is unremarkable. Nonetheless, in these Modern Frisian examples $v$ is not vocalized, and hence a crucial condition for Jorwert Breaking is absent. As such, these words present no clue for the grade of application of the sound change.

As regards Jorwert Breaking, we have just seen that within the Old Frisian period some words were affected completely, some were not affected at all, and there were some which were only partly affected. The files of the lexical database of Old Frisian charters in Groningen show us that after 1500 the heyday of Jorwert Breaking was over. On the basis of some modern dialectical varieties, such as the verbs bliuwe, etc., it can be concluded that Jorwert Breaking has not been applied across the board.

Did Jorwert Breaking cease to be active in the Middle and Modern Frisian periods? It looks like it, although it is hard to verify, since few words are eligible to test the hypothesis. In addition, in many cases it is hard to tell when a particular word found acceptance in Frisian. Be that as it may, I must confess that I have never heard the words ieu 'century' or Sieu 'inhabitant of the province of Zeeland' being pronounced in a broken way. On the other hand, it is probably going too far to conjecture that the tendency towards Jorwert Breaking completely disappeared. It may well be that a pronunciation /ljo.w/ for liuw 'lion' need not necessarily be traced back to the

138 K. Fokkema, 'De verzachting van enkele slotconsonanten na lange klinker of tweeklank in het Fries', K. Fokkema, Nei wider kimen. Kar út syn forsprate skriften (Groningen, 1969), 185-90. 
Middle Ages. And, on the basis of $W F T$, when would the broken variety of the words in (22) have gained acceptance?

(22)

\begin{tabular}{|c|c|c|}
\hline geau / & ‘(to) yawn’ & [gjo.w]/[gjo.wə] \\
\hline iuw & gill' & N], also [ki.w] \\
\hline $\begin{array}{l}\text { iiuw (meau) } \\
\text { iuwe }\end{array}$ & $\begin{array}{l}\text { 'mew, seagull' } \\
\text { 'to dawdle' }\end{array}$ & $\begin{array}{l}\text { [mjo.w], but also [mi.w] } \\
\text { [piu.ə],[pio.wə] }\end{array}$ \\
\hline
\end{tabular}

Uncertainty will - inevitably, I am afraid - remain concerning the exact commencement and extent of the broken pronunciations. As such, I would like to refer again to section 3, to the discussion of the easy transition between the various pronunciations of the word sleau. Nevertheless, without exaggeration, it can be maintained that the heyday of Jorwert Breaking must have been in the late Old Frisian period.

\section{CONCLUSION}

In Old West Frisian a falling diphthong, consisting of a front vowel and the glide $w$, may convert into a rising diphthong, or rather a triphthong, with a back vowel as a nucleus and with an initial glide $j$. This change, which for want of a better term I have dubbed 'Jorwert Breaking' here, can be characterized as natural, if we assume that the stress within the diphthong moved backwards. Only then can the process have followed in a direct way. In this derivation, vowel height remains constant. Thus, assuming a system of four vowel heights, the change was threefold: $i . w>j u . w, e . w>j o . w$ and $\varepsilon . w>j 0 . w$. This analysis clearly differs from the idea that was upheld until now, which assumed that for each vowel height the core of the change be performed at the highest level i.w $>$ ju.w.

Evidence for my analysis can be found in the phonetics of the process itself, and is supported by data from English and the dialect of the Frisian island of Schiermonnikoog. The main source of evidence, however, is provided by the Frisian words that underwent the change, although it turned out that tracing their precise development is far from easy. This is due to several factors, such as a lack of data and uncertainty about older spellings. A disturbing factor is the fact that in the relevant period other changes were taking place as well. At the input side we see raising of front vowels, and, more seriously, at the output of Jorwert Breaking, processes were active such as lowering in open syllables, raising before $l$ and $n$, and fronting and sometimes subsequent shortening of back vowels under the influence of preceding $j$. However, putting these influences aside, we see that the 
inventory of Frisian words offers clear support for the hypothesis that the change was a direct one. One point remains unresolved, however: it cannot be proven - nor disproven, for that matter - that the transition $\varepsilon . w>j 0 . w$ actually did occur. This is in line with the long-standing question of whether Old Frisian had one or two long e's.

Finally, among the three main branches of Frisian, Jorwert Breaking can only be observed in West Frisian. Its heyday must have been in the late Middle Ages, although it cannot be fully excluded that the transition also occurred at later periods. From the Old West Frisian data, a rather diffuse picture emerges. It is certainly not the case that all potential input words underwent the change, and sometimes only a part of the tokens that have come down to us show the case. 